\title{
Strategies and Outcome concerning interference with TV and 4G
}

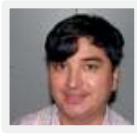

Moderator: Cristiano Akamine

Researcher and Professor - UNIVERSIDADE MACKENZIE/ SET

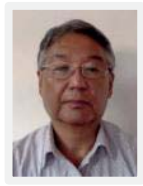

Interferência TV \& 4G

Speaker: Julio Omi

Visiting Professor at the Digital TV Laboratory - Mackenzie

Presbyterian University Presbiteriana Mackenzie (UPM).

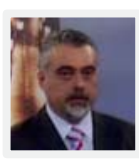

Convivência da TV digital com o SMP 700 MHz.

Dificuldades no switch off da TV analógica com o switch on do LTE

Speaker: Marcus A. R. Manhães

Senior Researcher - CPqD Foundation

Diretrizes definidas pelo GIRED para mitigação de interferências do 4G na TV

Speaker: Luiz Fausto

Diretoria de Tecnologia - SET / Especialista em Estratégia e Regulatório - Rede Globo 


\section{STRATEGIES AND OUTCOME} CONCERNING INTERFERENCE WITH

\section{TV AND 4G}

\section{Moderator: CRISTIANO AKAMINE}

Researcher and Professor - UNIVERSIDADE MACKENZIE/ SET

Em fevereiro deste ano a cidade de Rio Verde (GO) teve o sinal analógico da TV totalmente desligado. Foi a primeira cidade do Brasil a passar pela transição do sinal analógico para o digital.

Como toda migração, esta apresentou alguns problemas. Nós vamos apresentar os testes de laboratório realizados na última geração de receptores ISDB-TB e casos de interferências identificados em Rio Verde GO e convivência na harmonização para prevenção e correção. Em algumas condições de instalação, os resultamos mostraram que o sinal 4G/LTE pode interferir na recepção da TV digital.

- Interferência TV \& 4G

Speaker: Julio Omi Visiting Professor at the Digital TV Laboratory - Mackenzie Presbyterian University

O Laboratório em Pesquisas de TV Digital da Universidade Presbiteriano Mackenzie vem realizando pesquisas e testes sobre interferência dos Sistemas Móveis Digitais de Banda Larga - LTE, operando na faixa de $700 \mathrm{MHz}$ sobre os receptores de TV digital, desde 2013. Os primeiros testes com receptores de TV digital foram realizados mediante acordo com a SET, e seus resultados foram amplamente divulgados. O Laboratório continua realizando testes com os receptores de TV digital e apresenta, nesta ocasião, um resumo dos resultados focando nas características de Razão de Proteção -PR e Overloading Threshold - Oth dos receptores de TV digital.

- Convivência da TV digital com o SMP $700 \mathrm{MHz}$. Dificuldades no switch off da TV analógica com o switch on do LTE

\section{Speaker: Marcus A. R. Manhães}

Senior Researcher - CPqD Foundation

Análises das visitas técnicas efetuadas em Rio Verde-GO, oriundas de reclamações dirigidas ao serviço 147, da Seja Digital, que foram estimuladas a partir da campanha publicitária alertando toda a população local sobre a possibilidade de interferência do LTE na recepção de TV digital. Foram identificados os problemas graves para o radiodifusor, o resultado do filtro na mitigação e a influência do sinal LTE nas proximidades das ERBs.

- Diretrizes definidas pelo GIRED para mitigação de interferências do 4G na TV Speaker: Luiz Fausto

Technology Board - SET - Regulatory Strategy Specialist - Globo TV Network

Em julho de 2016, o GIRED aprovou as diretrizes a serem seguidas pela EAD / "Seja Digital" para mitigar eventuais problemas de interferência decorrentes da operação de redes $4 G / L T E$ na faixa de $700 \mathrm{MHz}$ sobre as recepções de TV. Serão introduzidos quais são os tipos de interferência e como eles devem ser tratados de forma preventiva e corretiva pela EAD / "Seja Digital" a partir das diretrizes aprovadas pelo GIRED, bem como os pontos de atenção que requerem acompanhamento do setor de radiodifusão. 

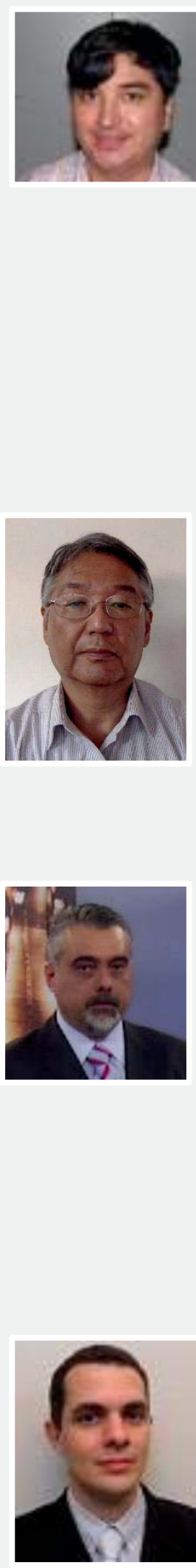

\section{CRISTIANO AKAMINE}

\section{Researcher and Professor - UNIVERSIDADE MACKENZIE/ SET}

$\mathrm{He}$ has an undergraduate degree in Electrical Engineering from the Mackenzie Presbyterian University (1999), Master's and Doctorate in Electrical Engineering from the State University of Campinas (2004/2011). He has been a researcher in the Digital TV Laboratory of the Mackenzie Presbyterian University since 1998; took an internship at the NHK Science and Technology Research Laboratories (STRL), holds various patents and has had several articles published. He is a professor on the Electrical Engineering course and the Graduate Program in Electrical Engineering and Computing (PPGEEC) of the Mackenzie Presbyterian University. He has experience in the field of Electrical Engineering, with the emphasis on Digital TV, digital communication, channel encoding, on-board systems, reconfigurable logic and software-defined radio. He is currently Specialist Visiting Professor at the Unicamp School of Technology and a participant on the Graduate Program of the School of Electrical Engineering and Computing (FEEC) at Unicamp.

\section{JULIO OMI}

Visiting Professor at the Digital TV Laboratory - Mackenzie Presbyterian University

Graduated in electronic engineering from the Polytechnic School at USP, and has a Master's in Engineering from the University of Tokyo.

He was Engineering Manager of the Radio Department at NEC do Brasil, and took part in the ITU-R, in the TG-8/1 and WP-8F Groups handling the IMT-2000 systems, and also at CITEL. He was a member of the Brazilian delegation to the Radio Communication Conferences in 1995, 1997 and 2000.

Took part in work at the Digital TV Laboratory of Mackenzie University, on the SBTVD project. $\mathrm{He}$ is Visiting Professor at the Digital TV Laboratory of the Mackenzie Presbyterian University.

\section{MARCUS A. R. MANHÃES}

\section{Senior Researcher - CPqD Foundation}

$\mathrm{He}$ is a researcher in broadcasting and telecommunications systems, working at the CPqD Foundation.

He was directly involved in the group that coordinated the process for defining the Digital TV system for Brazil, focusing on Interactivity Channel and Modulation solutions. Since 2012 he has produced studies for attributing the digital dividend, focusing on the Personal Mobile Service. He was representative consultant of Sinditelebrasil at the tests held at Pirenópolis$\mathrm{GO}$, becoming one of the leading figures in preparing the tests and the Laboratory and Field Reports produced by Anatel. He is currently providing technical consultancy to the Administrative Entity of the Process for Redistributing the Open TV Signal - EAD, participating in the technical specifications of the converters, antennae and filters. He recently coordinated and took part in the LTE-analog TV coexistence tests and is carrying out field tests in the processes for switching off analog TV and switching on LTE.

\section{LUIZ FAUSTO}

Technology Board - SET - Regulatory Strategy Specialist - Globo TV Network Professional Master's Degree in Applied Computing (UECE - 2015), Executive MBA on IT (UFRJ - 2011), extension course in Networks and Video over IP (UFRJ - 2009), Bachelor's Degree in Electrical Engineering with emphasis in Electronics (UFRJ/USU 2005). Currently working as Regulatory Strategy Specialist for Globo TV Network, member of the Delegation of Brazil in ITU-R (SG 6) and CITEL (PCC.II), member of the TV Reception Technical Group (GT-Rx) of the Brazilian TV Switch-Over Group (GIRED), member of the Technology Board Committee of the Brazilian Television Engineering Society (SET), member of the Technical Module of SBTVD Forum and member of the Harmonization Working Group of ISDB-T International Forum. 